\title{
Study of physico-chemical properties and in vitro antimicrobial activity of hydroxyapatites obtained from bone calcination
}

\author{
Cássio M. Resmim ${ }^{1} \cdot$ Mariane Dalpasquale $^{2}$. Nilce I. C. Vielmo ${ }^{1} \cdot$ Filipe Q. Mariani ${ }^{3} \cdot J^{\prime}$ uan C. Villalba ${ }^{2}$. \\ Fauze J. Anaissi ${ }^{2} \cdot$ Mirian M. Caetano ${ }^{1} \cdot$ Marcelo M. Tusi $^{1}$
}

Received: 22 April 2018 / Accepted: 22 December 2018 / Published online: 31 December 2018

(c) The Author(s) 2018

\begin{abstract}
Hydroxyapatite was obtained by bone calcinations. To study the calcination process, bovine and porcine bones were first autoclaved to remove fat and other non-bone tissues. They were then heated in an alumina pan in an oxidizing atmosphere of air, where simultaneous thermal analysis curves were recorded. To prepare the hydroxyapatites, bone samples were calcined at $850{ }^{\circ} \mathrm{C}$ and $1000{ }^{\circ} \mathrm{C}$ using a muffle furnace for $1 \mathrm{~h}$. The obtained materials were powdered using mortar and pestle, and sifted in a sieve $(60 \mathrm{mesh})$ without any additional purification or chemical treatment. The materials obtained were characterized by energy-dispersive X-ray spectroscopy, X-ray diffraction, and Fourier-transform infrared spectroscopy. The antimicrobial properties of these materials were determined through direct contact tests against Staphylococcus aureus. The natural hydroxyapatites obtained by bone calcination inhibited $S$. aureus growth, with the material obtained by calcination of bovine bones at $1000^{\circ} \mathrm{C}$, showing the best antimicrobial activity. These results indicated that bone wastes can be used to obtain hydroxyapatites with antimicrobial activity.
\end{abstract}

Keywords Hydroxyapatite $\cdot$ Staphylococcus aureus $\cdot$ Biomaterial $\cdot$ Bovine $\cdot$ Porcine

\section{Introduction}

Bones of vertebrate animals are composed of hydroxyapatites (30-70 wt \%), collagen, $\mathrm{Na}^{+}, \mathrm{Mg}^{+2}$, and $\mathrm{CO}_{3}^{-2}$ ions, and other minor compounds. The stoichiometric hydroxyapatite can be chemically synthesized, and it has formula $\mathrm{Ca}_{10}\left(\mathrm{PO}_{4}\right)_{6}(\mathrm{OH})_{2}$ and $\mathrm{Ca} / \mathrm{P}$ atomic ratio of 1.67 , although other stable hydroxyapatites can also have different $\mathrm{Ca} / \mathrm{P}$ ratios (Francis and Webb 1970; Dorozhkin and Epple 2002; Pebla et al. 2014; Abou Neel et al. 2016). This compound belongs to the calcium orthophosphate family, and it is the less soluble compound of its class in physiological aqueous

Marcelo M. Tusi

mmtusi@urisantiago.br

1 Universidade Regional Integrada do Alto Uruguai e das Missões-URI, Av. Batista Bonoto Sobrinho, 733, São Vicente, Santiago, RS 97700-000, Brazil

2 Universidade Estadual do Centro-Oeste-UNICENTRO, R. Simeão Varela de Sá, 03, Vila Carli, Guarapuava, PR 85040-080, Brazil

3 Faculdade Campo Real, R. Comendador Norberto, 1299, Santa Cruz, Guarapuava, PR 85040-080, Brazil environments. It has bioactive, biocompatible, and osteoconductive properties (Dorozhkin and Epple 2002; Barakat et al. 2008; Tan et al. 2013). The application of hydroxyapatite and calcium phosphate as biomaterials has been widely studied (Itoh et al. 2005; Oliveira et al. 2009; Tan et al. 2013; Zakaria et al. 2013; Shi et al. 2017).

Bacterial growth reduces the functionality and effectiveness of biomaterials as implants. In this context, the prevention of bacterial infections after the placement of an implant is crucial. Biomaterial-associated infections are generally resistant to antibiotics, and the removal of an infected implant is often the only possible solution, which, however, generates high costs for the health-care system and discomfort for the patient ( $\mathrm{Li}$ and Webster 2018). Antibiotics are thus critical for the success of orthopedic prosthetic surgeries. Antibiotic resistance is occurring in nearly all the bacteria, including the bacteria that most commonly cause orthopedic infections, such as $S$. aureus (Inzana et al. 2016; Li and Webster 2018). In arthroplasties, the infection rates are unfortunately high, and cause devastating effects on patients, such as reduction of their lifespan and increase in the failure rates of prostheses. Infections are also responsible for enormous medical costs, 
increase in morbidity, and patient dissatisfactions (Chen et al. 2007). Thus, it is important to determine the antimicrobial properties of biomaterials, especially against Escherichia coli e Staphylococcus aureus, as these are the most common source of contamination of prosthetic implants (Feitosa et al. 2016).

The physico-chemical and, consequently, antimicrobial properties of hydroxyapatite can be affected by synthesis conditions, namely reagent addition rate, reaction temperature, and others (Koutsopoulos 2002; Janusz and Skwarek 2009; Kehoe et al. 2011). Hydroxyapatite is commonly prepared by wet precipitation (Monmaturapoj 2008; Abidi and Murtaza 2014; Feitosa et al. 2016), sol-gel (Sanosh et al. 2009; Costescu et al. 2010; Agrawal et al. 2011), and hydrothermal method (Earl et al. 2006; Feitosa et al. 2016). However, the use of calcination (Mkukuma et al. 2004; Figueiredo et al. 2010; Fara and Abdullah 2016) and chemical treatment to obtain hydroxyapatite (Barakat et al. 2008) has also been reported. The extraction of hydroxyapatite from the bio-wastes is both a biologically safe (no external chemical is required) and economically desirable process (Barakat et al. 2008). Many reports describe the use of bio-wastes such as fish bones (Ozawa and Suzuki 2002; Fara and Abdullah 2016), bovine bones (Joschek et al. 2000), and bones and teeth of pigs (Xiaoying et al. 2007) to obtain hydroxyapatite.

In this work, nanostructured hydroxyapatites were obtained by calcination of bovine and porcine bones at two different temperatures. The obtained materials were characterized by X-ray diffraction (XRD), scanning electronic microscope (SEM), energy-dispersive spectroscopy (EDX), Fourier-transform infrared (FTIR), and the antimicrobial properties were evaluated against $S$. aureus. While the extraction of hydroxyapatite from bio-wastes has been largely explored, the antimicrobial properties of these materials and/or the influence of calcination temperature on the antimicrobial properties have so far remained elusive.

\section{Experimental}

\section{Bone collection and preparation}

Bovine and porcine bones were collected in supermarket butcher departments and kept cold in a refrigerator without any further treatment. The bones came from the diaphysis of bovine and porcine femur. To prepare hydroxyapatite, bones were first autoclaved for $1 \mathrm{~h}$ at one atmosphere to eliminate aggregated tissues and organic compounds (mostly fat and blood). Subsequently, fat and other non-bone tissues were manually removed and the bones were dried at $50{ }^{\circ} \mathrm{C}$ (Miyahara et al. 2007).

\section{Study of bone calcination}

To study the calcination of bones, simultaneous thermal analysis was performed using a Seiko SII Exstar 6000. Samples of bovine and porcine bones (about $15 \mathrm{mg}$ ) were heated in an alumina pan, with temperature increasing at a rate of $10{ }^{\circ} \mathrm{C} / \mathrm{min}$ from 25 to $1000{ }^{\circ} \mathrm{C}$ in an oxidizing atmosphere of air (Mondal et al. 2012).

\section{Hydroxyapatite preparation by bone calcination}

To obtain the hydroxyapatites, the bone samples (about $25 \mathrm{~g}$ ) were calcined at 850 and $1000{ }^{\circ} \mathrm{C}$ (at a rate of $10{ }^{\circ} \mathrm{C} / \mathrm{min}$ ) for $1 \mathrm{~h}$ using a Jung (model 0812) muffle furnace and static atmosphere (Miyahara et al. 2007; Figueiredo et al. 2010; Fara and Abdullah 2016). The materials were powdered using a mortar and pestle, and sifted in a 60-mesh sieve.

\section{Characterization and chemical analysis}

The $\mathrm{Ca} / \mathrm{P}$ ratio analysis of bone-derived hydroxyapatites was carried out using an energy-dispersive X-ray fluorescence spectrometry (EDXRF) instrument (Shimadzu, model EDX 8000). A spectral resolution of $132.58 \mathrm{eV}$ for $\mathrm{Mn} \mathrm{K}_{\alpha}$ was achieved, and the maximum count was $1088.5417 \mathrm{cps} / \mu \mathrm{A}$.

The X-ray diffraction analyses were performed using a Bruker diffractometer model D2 Phaser with $\mathrm{CuK} \alpha$ radiation source $(\lambda=0.15406 \mathrm{~nm})$. The XRD was recorded from $2 \theta=10-70^{\circ}$ with a step size of $0.05^{\circ}$ and a scanning time of $2 \mathrm{~s}$ per step. The crystallinity $\left(X_{\mathrm{C}}\right)$, corresponding to the fraction of crystalline phase present in the examined volume, was evaluated by the relation:

$\chi_{\mathrm{C}} \approx 1-\left(\frac{V_{112 / 300}}{I_{300}}\right)$,

where $I_{300}$ is the intensity of (300) reflection and $V_{112 / 300}$ is the intensity of the hollow between (112) and (300) reflections, which completely disappears in non-crystalline samples (Landi et al. 2000; Figueiredo et al. 2010). The mean crystallite size $(d)$ was calculated using the Scherrer equation:

$d=\frac{K \lambda}{B_{2 \theta} \cos \theta}$.

In this expression, $\lambda$ is the wavelength of the radiation, $\theta$ is the Bragg angle, and $\mathrm{B}_{2 \theta}$ indicates the line broadening at half the maximum intensity of the (002) reflection (Figueiredo et al. 2010).

The Fourier-transform infrared spectroscopy spectra were recorded on a Thermo Nicolet IR200 spectrometer in the 
wavenumber range $800-3700 \mathrm{~cm}^{-1}$. To prepare pellets, samples of the hydroxyapatite were first powdered in an agate mortar and then mixed with potassium bromide $(\mathrm{KBr})$. The mixture was pressed, while the system was evacuated with an oil pump.

\section{Antibacterial activity}

The antibacterial activity of the obtained hydroxyapatites against $S$. aureus (strain NEWP0023) was measured by direct contact in a solid medium, as previously described (Feitosa et al. 2016). Briefly, a bacterial suspension $\left(10^{5} \mathrm{cfu} /\right.$ $\mathrm{mL})$ was prepared in saline solution $(\mathrm{NaCl} 0.85 \%)$. Then, $2000 \mu \mathrm{L}$ of this suspension was transferred to an Eppendorf tube containing $10 \mathrm{mg}$ of the material, stirred, and then, $100 \mu \mathrm{L}$ of the mixture was spread onto agar plates. The plates were incubated at $37{ }^{\circ} \mathrm{C}$ for $24 \mathrm{~h}$. After this period, the number of bacterial colonies on each plate was counted. As growth-positive control, the bacterial suspension spreads onto agar plates in the absence of materials. All trials were performed in triplicate, and the results were normalized by the calculation of the arithmetic average. The inhibitory effect produced by each test material was calculated according to the equation:

$\mathrm{IF}=\left(\frac{C_{\text {control }}-C_{\text {test }}}{C_{\text {control }}}\right) \times 100 \%$,

where IF stands for the inhibitory effect, $C_{\text {control }}$ is the arithmetic average of the colony-forming units grown on control plates, and $C_{\text {test }}$ is the arithmetic average of the colony-forming units grown on test plates.

\section{Results and discussion}

\section{Study of bone calcination}

The thermal curves of the bone calcination process were obtained by simultaneous thermal analysis, as shown in Fig. 1. The thermal curves of the samples typically showed the occurrence of three successive processes of weight loss: the first below $200{ }^{\circ} \mathrm{C}$, the second between 200 and $600{ }^{\circ} \mathrm{C}$, and the third between 600 and $800{ }^{\circ} \mathrm{C}$. Above $800{ }^{\circ} \mathrm{C}$, the weight loss was negligible. The first process was attributed to the dehydration of the bone, also referred to as loss of surface water (Haberko et al. 2006; Figueiredo et al. 2010; Miculescu et al. 2012). The second process observed in the thermal curves was associated with the combustion of the bone organic matter, mainly collagen (Figueiredo et al. 2010; Miculescu et al. 2012). The third process of weight loss observed in the thermal curves was associated with the process of carbon dioxide release $\left(\mathrm{CO}_{2}\right)$, due to the decomposition of the carbonate ions $\left(\mathrm{CO}_{3}^{-2}\right)$ present in the lattice of hydroxyapatite (Haberko et al. 2006; Murugan et al. 2006; Figueiredo et al. 2010). The natural hydroxyapatite is a non-stoichiometric compound and contains in its lattice carbonate ions which substitute for hydroxyl ions. Phosphate ions lie on the surface of the crystal. Carbonate ions are the most abundant substitute in bone minerals (approximately 3-8 wt\%) (Murugan et al. 2006; Figueiredo et al. 2010). The data obtained in this work agree with the previous reports (Figueiredo et al. 2010), which showed the decomposition of carbonate ions at temperatures near $700{ }^{\circ} \mathrm{C}$.

On the other hand, according to the reports by Murugan et al. (2006), carbon dioxide is released during the bovine bone calcination in an air atmosphere which occurs at temperatures between 400 and $600^{\circ} \mathrm{C}$. The loss of most carbonate groups present in the carbonated hydroxyapatite, which naturally occurs during its extraction from bio-wastes by heating, is a problem which affects the biological properties of the final product (Barakat et al. 2008). The main results obtained by thermogravimetric analysis are presented in Table 1.

The data in Table 1 indicate that the bovine and porcine bones have similar water content, but the proportion of organic matter is slightly different. Strikingly, the profile of the curve obtained in differential thermal analysis indicates that fat can still be present in the porcine bones used in the experiment. This fat increases the amount of organic matter and, therefore, the collagen content indicated in Table 1 is to be considered as both collagen and fat, resulting in a lower yield of calcination. The carbonate ion content was about $3 \%$ in both bones.

The differential thermal analysis curves for bovine bones (Fig. 1) showed an exothermic peak with a maximum at $77^{\circ} \mathrm{C}$ and an accentuated exothermic peak with a maximum at about $330{ }^{\circ} \mathrm{C}$ and a shoulder at $430{ }^{\circ} \mathrm{C}$. For the porcine bone, it was possible to observe an exothermic peak at about $117^{\circ} \mathrm{C}$, an endothermic peak at $89^{\circ} \mathrm{C}$, an exothermic peak at $246{ }^{\circ} \mathrm{C}$, and two accentuated exothermic peaks at 339 and $463{ }^{\circ} \mathrm{C}$. Thus, compared to the bovine bone, the porcine bone presented a peak rather than a shoulder, possibly due to higher organic content. Both samples presented an exothermic peak within $720-750{ }^{\circ} \mathrm{C}$ range.

\section{Hydroxyapatite preparation}

Table 2 shows the properties of materials obtained by the calcination of bovine and porcine bones in a muffle furnace. The hydroxyapatite prepared by calcination of bones presented yield values in the range 59-66 wt \%. These values were independent of the calcination temperature, but the yields depended on the source of bone. The calcination of 
Fig. 1 Thermal curves obtained by simultaneous thermal analysis for the process of calcination of bones: $\mathbf{a}$ bovine and $\mathbf{b}$ porcine
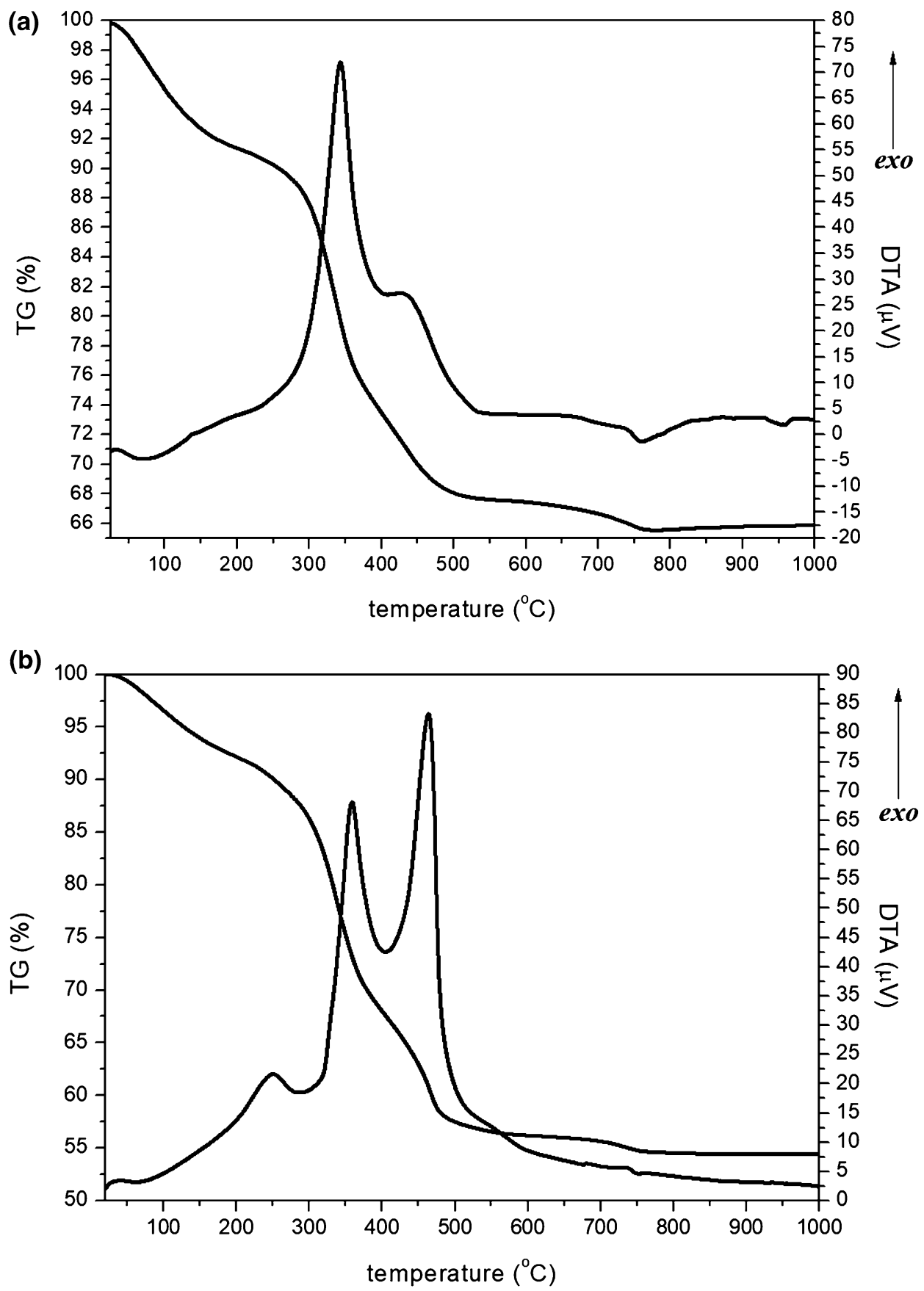

porcine bones resulted in lower yield, possibly due to the higher fat content and porosity of this bone.

\section{EDX analysis}

The materials were obtained by bone calcination presented $\mathrm{Ca} / \mathrm{P}$ ratio values between 1.96 and 2.02, higher than stoichiometric hydroxyapatite (1.67). Other authors (Joschek et al. 2000; Haberko et al. 2006) reported similar results. Higher $\mathrm{Ca} / \mathrm{P}$ ratio values compared to the stoichiometric hydroxyapatite may be due to the occurrence of either calcium and phosphorus compounds other than hydroxyapatite or Ca compounds deprived of phosphorus (e.g., formation of $\mathrm{CaO}$ or $\mathrm{CaCO}_{3}$ ) (Francis and Webb 1970; Barakat et al. 2008; Figueiredo et al. 2010; Doostmohammadi et al. 2011; Bano et al. 2017). Besides the presence of calcium (Ca) and phosphorus (P), EDX analysis showed the presence of aluminum (Al), strontium $(\mathrm{Sr})$, silicon $(\mathrm{Si})$, potassium $(\mathrm{K})$, zinc $(\mathrm{Zn})$, and cooper $(\mathrm{Cu})$, in agreement with previously published studies (Miculescu et al. 2012; Pebla et al. 2014). 
Table 1 Amount of the main components of samples of bovine and porcine bones estimated using the thermal curves and $\mathrm{Ca} / \mathrm{P}$ ratio of hydroxyapatite obtained after the thermogravimetric analysis

\begin{tabular}{lcc}
\hline Attribution & Bovine & Porcine \\
\hline $\mathrm{H}_{2} \mathrm{O}(\mathrm{wt} \%)\left(T<200{ }^{\circ} \mathrm{C}\right)$ & 8.7 & 8.2 \\
Collagen $(\mathrm{wt} \%)\left(200<T<600{ }^{\circ} \mathrm{C}\right)$ & 26.2 & 39.1 \\
Hydroxyapatite $(\mathrm{wt} \%)^{\mathrm{a}}$ & 65.1 & 52.7 \\
$\mathrm{CO}_{3}^{-2}(\mathrm{wt} \%)^{\mathrm{b}}\left(600{ }^{\circ} \mathrm{C}<T<800^{\circ} \mathrm{C}\right)$ & 2.8 & 3.0 \\
\hline
\end{tabular}

$\mathrm{a} \%=100-\left(\% \mathrm{H}_{2} \mathrm{O}+\%\right.$ collagen $)$

${ }^{\mathrm{b}} \%=\left[\left(w_{600}{ }^{\circ} \mathrm{C}-w_{800}{ }^{\circ} \mathrm{C}\right) / w_{600}{ }^{\circ} \mathrm{C}\right] \times 100 \%$

${ }^{\mathrm{c}} \mathrm{Ca} / \mathrm{P}$ ratio of clear bone before calcination

Table 2 The yield of calcination, $\mathrm{Ca} / \mathrm{P}$ ratio, mean crystallite size, and crystallinity of materials obtained by the calcination of bones in a muffle furnace

\begin{tabular}{llllll}
\hline Properties & \multicolumn{2}{c}{ Bovine } & & \multicolumn{2}{c}{ Porcine } \\
\cline { 2 - 3 } \cline { 6 - 7 } \cline { 6 - 7 } & $850{ }^{\circ} \mathrm{C}$ & $1000{ }^{\circ} \mathrm{C}$ & & $850{ }^{\circ} \mathrm{C}$ & $1000{ }^{\circ} \mathrm{C}$ \\
\hline Yield (wt\%) & 65 & 65 & & 59 & 59 \\
Ca/P ratio & 2.02 & 1.98 & & 2.00 & 1.96 \\
Crystallite (nm) & 19 & 19 & & 22 & 19 \\
Crystallinity & 0.70 & 0.84 & & 0.24 & 0.70 \\
Antimicrobial activity (\%) & 30 & 81 & & 38 & 56 \\
\hline
\end{tabular}

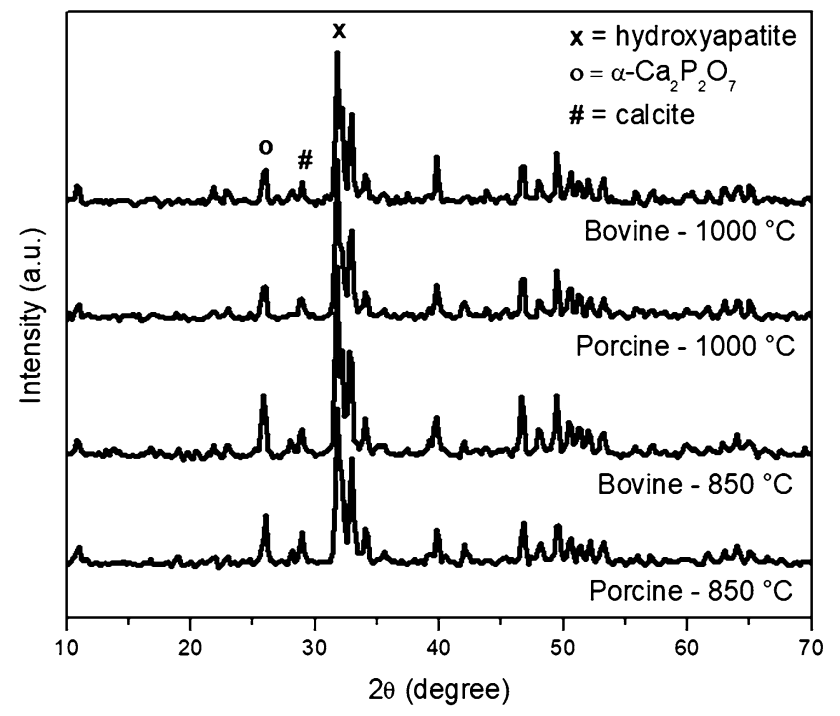

Fig. 2 X-ray diffractograms of nanohydroxyapatite samples obtained by calcination of bones

\section{X-ray diffractometry}

Figure 2 presents the X-ray diffractograms of bone calcination products. All the obtained materials presented hydroxyapatite as the main phase. All the obtained

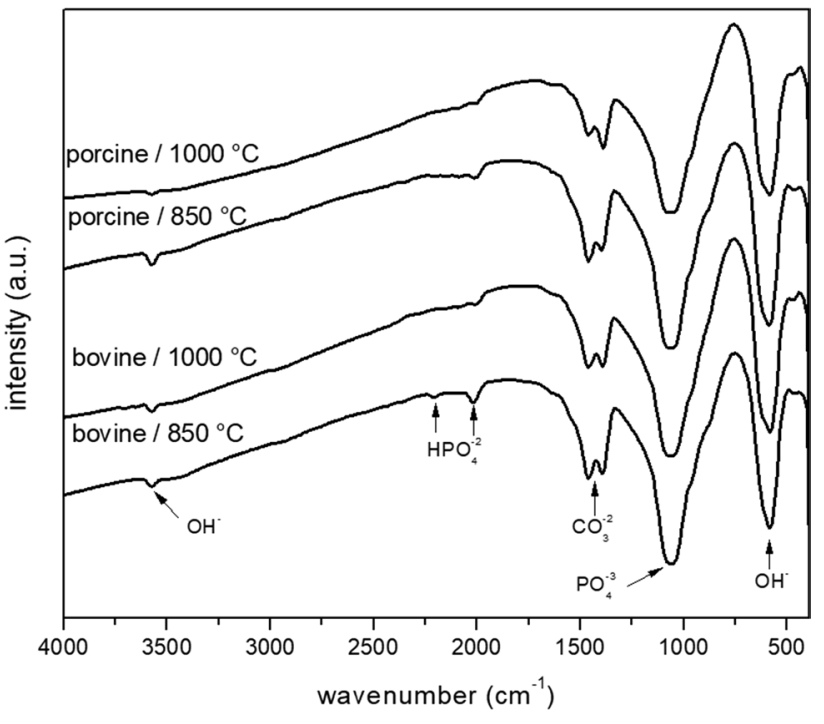

Fig. 3 FTIR spectra of nanohydroxyapatite samples obtained by calcination of bones

materials presented peaks associated with calcite phase (ICDD 5-586). The hydroxyapatites obtained from bovine bones (ICDD 84-1998) had a different lattice structure than the hydroxyapatites obtained from porcine bones (ICDD 73-1731). Apparently, the materials obtained from bovine bones showed peaks associated with the $\alpha-\mathrm{Ca}_{2} \mathrm{P}_{2} \mathrm{O}_{7}$ phase (ICDD 9-345), while materials obtained from porcine bones presented hydroxyapatite as the only phase. The formation of secondary phases, as observed, is associated with the degradation of hydroxyapatite due to high temperature. An example is a process in the range of temperature between 600 and $800{ }^{\circ} \mathrm{C}$, associated with the decomposition of the carbonate ions present in the hydroxyapatite lattice (Landi et al. 2000; Miculescu et al. 2012).

The values of crystallinity degrees (Table 2) were in the range $0.24-0.84 \%$. The lower crystallinity was registered for the material obtained by the calcination of porcine bones at $850{ }^{\circ} \mathrm{C}$, while the higher crystallinity was observed for the material obtained by calcination of bovine bones at $1000{ }^{\circ} \mathrm{C}$. This result is in accordance with other studies, which report that, in the extraction of hydroxyapatite by calcination of bones, mean particle size and crystallinity increase with the increase in the temperature of calcination (Figueiredo et al. 2010; Fara and Abdullah 2016). The materials obtained by calcination of bovine bones presented mean crystallite size of $19 \mathrm{~nm}$, while the materials obtained by calcination of porcine bones showed mean crystallite size of $22 \mathrm{~nm}$ for the calcination temperature of $850{ }^{\circ} \mathrm{C}$ and $19 \mathrm{~nm}$ for the calcination temperature of $1000{ }^{\circ} \mathrm{C}$. Mean crystallite size was calculated using the Scherrer formula. 


\section{Infrared spectra}

To characterize the chemical groups in hydroxyapatite obtained by calcination of bones, an FTIR analysis was performed (Fig. 3). All FTIR spectra presented the same peaks, independent of bone used and temperature of calcination. The observed bands corresponded to hydroxyl $\left(\sim 3571 \mathrm{~cm}^{-1}\right)$, phosphate $\left(1057 \mathrm{~cm}^{-1}\right.$ and $\left.578 \mathrm{~cm}^{-1}\right)$, and carbonate (1396 and $1458 \mathrm{~cm}^{-1}$ ) (Rau et al. 2004; Figueiredo et al. 2010; Laranjeira et al. 2016; Petrova et al. 2016). The presence of carbonate bands in the FTIR spectroscopy may be explained by residual carbonate ions that were not removed during the calcination process, corroborating the $\mathrm{X}$-ray diffraction data. However, the incomplete elimination of carbonate ions contradicts the results of thermal analysis and is probably due the technical reason. In detail, the experiment in muffle furnace requires a larger bone piece (and, thus, higher bone weight) compared to the thermal analysis and, consequently, it is likely that the time used in thermal treatment to prepare the hydroxyapatite was not enough to eliminate the carbonate in the muffle furnace. The interpretation of the remaining bands (2013 and $2206 \mathrm{~cm}^{-1}$ ) is at the moment still under investigation. An interesting idea, according to Rau and coworkers, is that these bands are by-products of processes of association, liberation, or interaction with molecules polluting the matrix (Rau et al. 2004).

\section{Antibacterial activities}

Figure 4 presents images of cultures of $S$. aureus, used to determine the antimicrobial activity of the hydroxyapatites obtained in this study. Bacteria incubated in the presence of hydroxyapatite formed less colonies than the control (bacteria incubated in the absence of the tested material), suggesting a possible inhibitory effect of the hydroxyapatite on the growth of $S$. aureus. The materials obtained from bovine bones at 850 and $1000{ }^{\circ} \mathrm{C}$ showed a growth inhibitory effect of $30 \%$ and $81 \%$, respectively, while the hydroxyapatites obtained by calcination of porcine bones at 850 and $1000{ }^{\circ} \mathrm{C}$ were able to inhibit $38 \%$ and $56 \%$ of the bacterial cells, respectively.

These data are in agreement with the results of other authors (Feitosa et al. 2016) that observed inhibitions of 97\% and 95\% for the S. aureus growth using powdered hydroxyapatites prepared by co-precipitation and the hydrothermal method, respectively. On the other hand, others (Predoi et al. 2016) reported that a thin film of pure hydroxyapatite deposited on Si disks did not show any antimicrobial activity against $S$. aureus. It is likely that the presentation of the tested material influences the results in antimicrobial activity tests, possibly due to the solubility of the hydroxyapatite. A variety of methods of determining antimicrobial activity have been studied and the results obtained are profoundly influenced by the method selected, microorganisms used to carry out the test, and the degree of solubility of each test compound (Valgas et al. 2007). It is known that hydroxyapatite is an insoluble material, especially in an alkaline medium (Semdé et al. 2012). The Müeller-Hinton medium and phosphate-buffer saline (PBS) have a pH close to 7.2. Therefore, the hydroxyapatite is practically insoluble in these media and its diffusion rate is very small. In the case of a thin film of pure hydroxyapatite deposited on a Si disk, it is likely that the interaction between the ceramic material and the microorganisms is insufficient to inhibit bacterial growth. Instead, in the case of powdered hydroxyapatite, the surface area is larger, increasing the interaction between the material and the bacteria and, consequently, increasing the inhibitory effect.

Gram-positive bacteria such as $S$. aureus have a cell wall composed of a thick layer of peptidoglycan, a polymer of carbohydrates and charged amino acids, which makes them highly hydrophilic (Harris et al. 2002; Ragab et al. 2014; Feitosa et al. 2016). The antibacterial activity observed for hydroxyapatite against $S$. aureus may be associated with the hydrophilic nature of this material due to the presence of hydroxyl groups, which may favor the interaction with the cell wall of Gram-positive bacteria (Feitosa et al. 2016). The antimicrobial activity of hydroxyapatite can be attributed to the production of reactive oxygen species $\left(\mathrm{OH}^{-}, \mathrm{H}_{2} \mathrm{O}_{2}\right.$, and $\mathrm{O}_{2}^{-2}$ ) on the surface of the hydroxyapatite nanoparticles, linked with fatal damage to the bacteria. Another possible explanation for the antibacterial effect is that the abrasive surface ordering (i.e., texturing) of the hydroxyapatite due to surface defects and aggregates can contribute to the mechanical damage to the bacterial cell membrane (Ragab et al. 2014).

\section{Conclusions}

Nanostructured hydroxyapatite was prepared by calcination of bovine and porcine bones at different temperatures with good yield. The hydroxyapatites obtained by calcination of bones showed a mixture of phases containing hydroxyapatite and calcium carbonate phases. FTIR spectra indicated that all materials presented peaks associated with phosphate, hydroxyl, and carbonate groups. The $\mathrm{Ca} / \mathrm{P}$ ratio values of obtained materials were acceptable for hydroxyapatite materials, but these values were higher compared to the theoretical values, probably due to the formation of the calcite phase. The natural hydroxyapatites obtained by calcination of bovine and porcine bones could inhibit $S$. aureus growth, with the material prepared by calcination of bovine bones at $1000{ }^{\circ} \mathrm{C}$ presenting an antibacterial activity against $S$. aureus superior compared to other materials. The antimicrobial activity was weakly 
Fig. 4 Determination of the antimicrobial activity of natural hydroxyapatites against $S$. aureus. a control for determination of antimicrobial activity of hydroxyapatites obtained from bovine bone; $\mathbf{b}$ hydroxyapatite obtained from calcination of bovine bone at $850{ }^{\circ} \mathrm{C}$; c hydroxyapatite obtained from calcination of bovine bone at $1000{ }^{\circ} \mathrm{C} ; \mathbf{d}$ control for determination of antimicrobial activity of hydroxyapatites obtained from porcine bone; $\mathbf{e}$ hydroxyapatite obtained from calcination of porcine bone at $850{ }^{\circ} \mathrm{C}$; $\mathbf{f}$ hydroxyapatite obtained from calcination of porcine bone at $1000{ }^{\circ} \mathrm{C}$
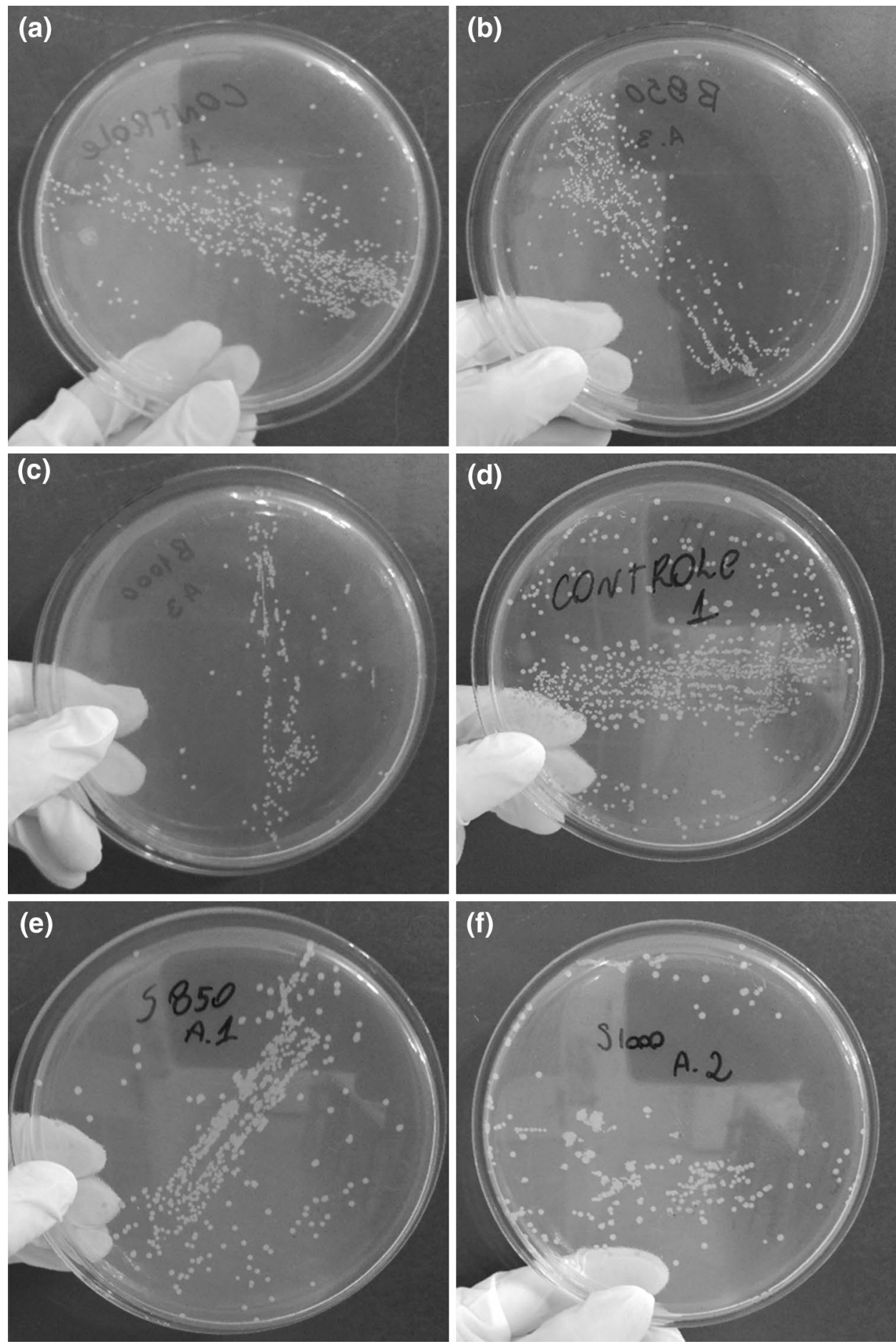

influenced by the source of bone used, and higher calcination temperatures led to greater inhibitions of $S$. aureus growth.

Acknowledgements The authors would like to thank the Universidade Regional Integrada do Alto Uruguai e das Missões (URI-Câmpus de Santiago-RS) and the Universidade Estadual do Centro-Oeste (UNICENTRO-PR) for their support.

\section{Compliance with ethical standards}

Conflict of interest The authors declare that they have no conflict of interest.

Research involving human and/or animal None of the experiments conducted in this study was performed on human participants or animals. 
Open Access This article is distributed under the terms of the Creative Commons Attribution 4.0 International License (http://creativeco mmons.org/licenses/by/4.0/), which permits unrestricted use, distribution, and reproduction in any medium, provided you give appropriate credit to the original author(s) and the source, provide a link to the Creative Commons license, and indicate if changes were made.

\section{References}

Abidi SSA, Murtaza Q (2014) Synthesis and characterization of nano-hydroxyapatite powder using wet chemical precipitation reaction. J Mater Sci Technol 30:307-310. https://doi. org/10.1016/j.jmst.2013.10.011

Abou Neel EA, Aljabo A, Strange A, Ibrahim S, Coathup M, Young AM, Bozec L, Mudera V (2016) Demineralization-remineralization dynamics in teeth and bone. Int J Nanomed 11:47434763. https://doi.org/10.2147/IJN.S107624

Agrawal K, Singh G, Puri D, Prakash S (2011) Synthesis and characterization of hydroxyapatite powder bys-gel method for biomedical application. J Min Mater Charact Eng 10:727-734. https://doi.org/10.4236/jmmce.2011.108057

Bano N, Jikan SS, Basri H, Bakar SASA, Nuhu AH (2017) Natural hydroxyapatite extracted from bovine bone. J Sci Technol 9:22-28

Barakat NAM, Khalil KA, Sheikh FA, Omran AM, Gaihre B, Khil SM, Kim HY (2008) Physiochemical characterizations of hydroxyapatite extracted from bovine bones by three different methods: extraction of biologically desirable Hap. Mater Sci Eng C 28:1381-1387. https://doi.org/10.1016/j.msec.2008.03.003

Chen W, Oh S, Ong AP, Oh N, Liu Y, Courtney HS, Appleford M, Ong JL (2007) Antibacterial and osteogenic properties of silver-containing hydroxyapatite coatings produced using a sol gel process. J Biomed Mater Res A 82:899-906. https://doi. org/10.1002/jbm.a.31197

Costescu A, Pasuk I, Ungureanu F, Dinischiotu A, Costache M, Huneau F, Galaup S, Le Coustumer P, Predoi D (2010) Physico-chemical properties of nano-sized hexagonal hydroxyapatite powder synthesized by sol-gel. Dig J Nanomater Biostruct 5:989-1000

Doostmohammadi A, Monshi A, Fathi MH, Braissant O (2011) A comparative physico-chemical study of bioactive glass and bone-derived hydroxyapatite. Ceram Int 37:1601-1607. https ://doi.org/10.1016/j.ceramint.2011.03.009

Dorozhkin SV, Epple M (2002) Biological and medical significance of calcium phosphates. Angew Chem Int Ed Engl 41:3130-3146. https://doi.org/10.1002/1521-3773(20020 902)41:17\%3c3130:AID-ANIE3130\%3e3.0.CO;2-1

Earl JS, Wood DJ, Milne SJ (2006) Hydrothermal synthesis of hydroxyapatite. J Phys Conf Ser 26:268-271

Fara A, Abdullah HZ (2016) Influence of calcination temperature on the microstructure and crystallographic properties of hydroxyapatite from black Tilapia fish scale. Mater Sci Forum 840:151-155. https://doi.org/10.4028/www.scientific.net/MSF.840.151

Feitosa GT, Santos MVB, Barreto HM, Nunes LCC, Osajima JA, Silva Filho EC (2016) Hydroxyapatites obtained from different routes and their antimicrobial properties. Mater Sci Forum 869:890-895. https://doi.org/10.4028/www.scientific.net/MSF.869.890

Figueiredo M, Fernando A, Martins G, Freitas J, Judas F, Figueiredo $\mathrm{H}$ (2010) Effect of the calcination temperature on the composition and microstructure of hydroxyapatite derived from human and animal bone. Ceram Int 36:2383-2393. https://doi. org/10.1016/j.ceramint.2010.07.016

Francis MD, Webb NC (1970) Hydroxyapatite formation from a hydrated calcium monohydrogen phosphate precursor. Calcif Tissue Res 6:335-342
Haberko K, Bućko MM, Miecznik JB, Haberko M, Mozgawa W, Panz T, Pyda A, Zarębski J (2006) Natural hydroxyapatite-its behaviour during heat treatment. J Eur Ceram Soc 26:537-542. https://doi.org/10.1016/j.jeurceramsoc.2005.07.033

Harris LG, Foster SJ, Richards RG (2002) An introduction to Staphylococcus aureus, and techniques for identifying and quantifying $S$. aureus adhesins in relation to adhesion to biomaterials: review. Eur Cell Mater 4:39-60

Inzana JA, Schwarz EM, Kates SL, Awad HA (2016) Biomaterials approaches to treating implant-associated osteomyelitis. Biomaterials 81:58-71. https://doi.org/10.1016/j.biomaterials.2015.12.012

Itoh S, Kikuchi M, Koyama Y, Matumoto HN, Takakuda K, Shinomiya Tanaka J (2005) Development of a novel biomaterial, hydroxyapatite/collagen (HAp/Col) composite for medical use. Biomed Mater Eng 15:29-41

Janusz W, Skwarek E (2009) The study of the properties of the hydroxyapatite/electrolyte interface. Annales Universitatis Mariae Curie Skłodowska Lublin 64:11-20. https://doi.org/10.2478/ v10063-008-0003-X

Joschek S, Nies B, Krotz R, Göpferich A (2000) Chemical and physicochemical characterization of porous hydroxyapatite ceramics made of natural bone. Biomaterials 21:1645-1658. https://doi. org/10.1016/S0142-9612(00)00036-3

Kehoe S, Ardhaoui M, Stokes J (2011) Design of experiments study of hydroxyapatite synthesis for orthopaedic application using fractional factorial design. J Mater Eng Perform 20:1423-1437. https ://doi.org/10.1007/s11665-010-9704-3

Koutsopoulos S (2002) Synthesis and characterization of hydroxyapatite crystals: a review study on the analytical methods. J Biomed Mater Res 15:600-612. https://doi.org/10.1002/jbm.10280

Landi E, Tampieri A, Celotti G, Sprio S (2000) Densification behaviour and mechanisms of synthetic hydroxyapatites. J Eur Ceram Soc 20:2377-2387. https://doi.org/10.1016/S0955-2219(00)00154-0

Laranjeira MS, Moço A, Ferreira J, Coimbra S, Costa E, Santos-Silva A, Ferreira PJ, Monteiro FJ (2016) Different hydroxyapatite magnetic nanoparticles for medical imaging: its effects on hemostatic, hemolytic activity and cellular cytotoxicity. Colloid Surface B 146:363-374. https://doi.org/10.1016/j.colsurfb.2016.06.042

Li B, Webster TJ (2018) Bacteria antibiotic resistance: new challenges and opportunities for implant-associated orthopaedic infections. J Orthop Res 36:22-32. https://doi.org/10.1002/jor.23656

Miculescu F, Stan GE, Ciocan LT, Miculescu M, Berbecaru A, Antoniac I (2012) Cortical bone as resource for producing biomimetic materials for clinical use. Dig J Nanomater Biostruct 7:1667-1677

Miyahara RY, Gouvêa D, Toffoli SM (2007) Obtenção e caracterização de cinza de ossos bovinos visando à fabricação de porcelana de ossos_bone China. Cerâmica 53:234-239. https://doi. org/10.1590/S0366-69132007000300004

Mkukuma LD, Skakle JMS, Gibson IR, Imrie CT, Aspden RM, Hukins DWL (2004) Effect of the proportion of organic material in bone on thermal decomposition of bone mineral: an investigation of a variety of bones from different species using thermogravimetric analysis coupled to mass spectrometry, high-temperature $\mathrm{X}$-ray diffraction, and Fourier transform infrared spectroscopy. Calcif Tissue Int 75:321-328. https://doi.org/10.1007/s0022 3-004-0199-5

Mondal S, Mondal B, Dey A, Mukhopadhyay SS (2012) Studies on processing and characterization of hydroxyapatite biomaterials from different bio-wastes. J Miner Mater Charact Eng 11:55-67. https://doi.org/10.4236/jmmce.2012.111005

Monmaturapoj N (2008) Nano-size hydroxyapatite powders preparation by wet-chemical precipitation route. $\mathrm{J}$ Met Mater Miner 18:15-20

Murugan R, Ramakrishna S, Rao KP (2006) Nanoporous hydroxycarbonate apatite scaffold made of natural bone. Mater Lett 60:2844-2847. https://doi.org/10.1016/j.matlet.2006.01.104 
Oliveira JM, Silva SS, Malafaya PB, Rodrigues MT, Kotobuki N, Hirose M, Gomes ME, Mano JF, Ohgushi H, Reis RL (2009) Macroporous hydroxyapatite scaffolds for bone tissue engineering applications: physicochemical characterization and assessment of rat bone marrow stromal cell viability. J Biomed Mater Res A 91:175-186. https://doi.org/10.1002/jbm.a.32213

Ozawa M, Suzuki S (2002) Microstructural development of natural hydroxyapatite Originated from fish-bone waste through heat treatment. J Am Ceram Soc 85:1315-1317. https://doi. org/10.1111/j.1151-2916.2002.tb00268.x

Pebla E, Besherat LK, Palaia G, Tenore G, Migliau G (2014) Nanohydroxyapatite and its applications in preventive, restorative and regenerative dentistry: a review of literature. Ann Stomatol 5:108-114

Petrova I, Kalinkevich O, Pogorielov M, Kalinkevich A, Stanislavov A, Sklyar A, Danilchenko S, Yovcheva T (2016) Dielectric and electric properties of new chitosan-hydroxyapatite materials for biomedical application: dielectric spectroscopy and corona treatment. Carbohydr Polym 151:770-778. https://doi.org/10.1016/j. carbpol.2016.05.110

Predoi D, Popa CL, Chapon P, Groza A, Iconaru SL (2016) Evaluation of the antimicrobial activity of different antibiotics enhanced with silver-doped hydroxyapatite thin films. Materials 9:778-795. https ://doi.org/10.3390/ma9090778

Ragab HS, Ibrahim FA, Abdallah F, Al-Ghamdi AA, El-Tantawy F, Radwan N, Yakuphanoglu F (2014) Synthesis and in vitro antibacterial properties of hydroxyapatite nanoparticles. IOSR J Pharm Biol Sci 9:77-85. https://doi.org/10.9790/3008-09167785

Rau JV, Cesaro SN, Ferro D, Barinov SM, Fadeeva IV (2004) FTIR study of carbonate loss from carbonated apatites in the wide temperature range. J Biomed Mater Res B 71:441-447. https://doi. org/10.1002/jbm.b.30111

Sanosh KP, Chu MC, Balakrishnan A, Kim TN, Cho SJ (2009) Preparation and characterization of nano-hydroxyapatite powder using sol-gel technique. Bull Mater Sci 32:465-470. https://doi. org/10.1007/s12034-009-0069-x

Semdé R, Gondi RFG, Sombié BC, Yaméogo BGJ, Ouédraogo M (2012) Effect of hydroxyapatite on the physicochemical characteristics of a gentamicin-loaded monoolein gel intended to treat chronic osteomyelitis. J Adv Pharm Technol Res 3:100-105. https ://doi.org/10.4103/2231-4040.97283

Shi P, Wang Q, Yu C, Fan F, Liu M, Tu M, Lu W, Du M (2017) Hydroxyapatite nanorod and microsphere functionalized with bioactive lactoferrin as a new biomaterial for enhancement bone regeneration. Colloids Surf B Biointerfaces 155:477-486. https ://doi.org/10.1016/j.colsurfb.2017.04.042

Tan L, Yu X, Wan P, Yang K (2013) Biodegradable materials for bone repairs: a review. J Mater Sci Technol 29:503-513. https://doi. org/10.1016/j.jmst.2013.03.002

Valgas C, Souza SM, Smânia EFA, Smânia A Jr (2007) Screening methods to determine antibacterial activity of natural products. Braz J Microbiol 38:369-380. https://doi.org/10.1590/S1517 $-83822007000200034$

Xiaoying L, Yongbin F, Dachun G, Wei C (2007) Preparation and characterization of natural hydroxyapatite from animal hard tissues. Key Eng Mater 342-343:213-216. https://doi.org/10.4028/www. scientific.net/KEM.342-343.213

Zakaria SM, Sharif Zein SH, Othman MR, Yang F, Jansen JA (2013) Nanophase hydroxyapatite as a biomaterial in advanced hard tissue engineering: a review. Tissue Eng Part B Rev 19:431-441. https://doi.org/10.1089/ten.TEB.2012.0624

Publisher's Note Springer Nature remains neutral with regard to jurisdictional claims in published maps and institutional affiliations. 